\title{
CHARACTERISTICS OF PERSONS REGISTRATED DUE TO CANNABINOID ABUSE IN CROATIA - DO WE HAVE ENOUGH EFFECTIVE INTERVENTION?
}

\author{
Dora Milaković ${ }^{1}$, Danijela Stimac Grbić ${ }^{1,2}$, Maja Valentić ${ }^{2}$, Gorka Vuletić ${ }^{3}$ \& Ivana Pavić Šmetin ${ }^{2}$ \\ ${ }^{1}$ University of Zagreb, Faculty of Medicine, School of Public Health, Zagreb, Croatia \\ ${ }^{2}$ Croatian Institute of Public Health. Zagreb, Croatia \\ ${ }^{3}$ University of Osijek, Faculty of Humanities and Social Sciences, Department of Psychology, Osijek, Croatia
}

received: 22.2.2021;

revised: 15.4.2021;

accepted: 3.5 .2021

\section{SUMMARY}

Background: It is known that cannabis increases mood, decreases anxiety and causes mild euphoria, but also it can cause serious mental diseases. Previous studies showed harmful effects of cannabis and the aim of this study is to show characteristics of persons registrated because of cannabinoids abuse in Croatia in the period 2008-2018 and show effectiveness of interventions using statistic methods.

Subjects and methods: Research data were collected based on the national Registry of Treated Psychoactive Drug Abusers in period 2008 to 2018 and included 10533 registrated persons. Statistical analysis was performed by chi-square test and binary logistic regression.

Results: Results showed that men and very young people took cannabinoids more often than women and older people. There was a changing trend of registrated people in a ten-year period. The most commonly used intervention of obligatory healthcare treatment is consultation, but the difference between apstinents and people with unchanged status isn't statistically significant. The most people are referred by repressive mechanism and they are more likely to have apstinent status compared to unrepressive source of referral, with one exception - referred by the family. The highest probability of abstinence have those referred by the center for social welfare.

Conclusions: Registrated people were mostly referred by repressive way, which makes question of its efficiency and prevention of long term addiction, because system like that more likely stigmatizes and punishes young people, opposite to giving support and help.

Key words: cannabis - interventions - law regulations - obligatory healthcare treatment

\section{INTRODUCTION}

Cannabis is a term for all products produced from plant Cannabis sativa, whereas cannabinoids are its biological active substances. As addiction substances, the most commonly used forms of cannabis are marijuana, which is produced from dry flowers and leaves of the plant and hashish, a resin obtained from marijuana. It is usually introduced into the body through smoking, but also through inhalation. They have psychoactive effect because of cannabinoid delta-tetrahydrocannabinol (THC). Marijuana contains $5-15 \%$ of THC and hashish a little bit more (Turner et al. 2014, ElSohly et al. 2017). It is known that cannabis increases mood, decreases anxiety and causes mild euphoria, which are the main causes of increasing of its use within young people (Turner et al. 2014, Mehanović et al. 2019), especially within boys (Teesson et al. 2015, Osuch et al. 2013, Katalinić \& Huskić 2017), but also causes addiction and in $10 \%$ of cases it can cause serious mental diseases, such as psychosis and schizophrenia, bipolar disease and depression (Turner et al. 2014, Arias et al. 2013). Furthermore, daily use is associated with higher risk for lungs cancer, bronchitis, angina pectoris and hearth attack. Also, it has cognitive effects, such as concentration difficulties, problem solving, making deci- sions and studying (Turner et al. 2014). People younger than 18 years old are especially in danger because of their nerve system which is more sensitive to psychoactive effects of cannabis (Turner et al. 2014, Simpson $\&$ Magid 2016). In Republic of Croatia use of cannabis is illegal (Zakon o suzbijanju zlouporabe opojnih droga 2001), but use for personal necessities has been decriminalized since 2013, which means that it is not criminal, but civil offence (Ministarstvo pravosuđa $\mathrm{i}$ uprave 2013), whose possible interventions, following Misdemeanor law, are obligatory healthcare treatment, fine, imprisonment, juvenile imprisonment i suspended sentence (Prekršajni zakon 2019). Following the article 32 of the Law on Amendments to the Anti-drug Abuse Act, if the offence was committed for the first time, the offender can get obligatory treatment in healthcare institution without imposition of fine or imprisonment up to 90 days and with fine or imprisonment up to 90 days if it is the case of a drug addict or an occasional drug user (Zakon o izmjenama i dopunama Zakona o suzbijanju zlouporabe droga 2019). Previous studies showed harmful effects of cannabis and the purpose of this study is to examine characteristics of people's registrated due to cannabinoids abuse in Republic of Croatia in the period from 2008 to 2018 , to analyse those characteristics in relation to conducted interven- 
tions and compare them with interventions in other European countries. Netherlands, Italy, France, Romania and Czech Republic are especially interesting to be compared with Croatia because they have legal regulations with the use of cannabis in medical treatments (Bifulco \& Pisanti 2015).

\section{SUBJECTS AND METHODS}

\section{Subjects}

Research dana were collected based on national Registry of Treated Psychoactive Drug Abusers in period from year 2008 to 2018, which is conducted by the Croatian Institute of Public Health, and included 10 533 registrated persons. Data on persons treated for psychoactive drug abuse were collected from hospitals, specialist - consultant services, service for prevention and outpatient treatment and therapeutic communities ${ }^{6}$. All data about respondents are anomized, which means processed in such a way that no one, not even the one who processed the data, can connect them with certain persons, so it doesn't require ethics committee approval.

\section{Methods}

This research paper gives analysis of existing data from the national Registry of Treated Psychoactive Drug Abusers. The collection of data for the register is legally determined by the program of collecting health statistical data. Publishing such a paper is a way to analyze and present the results of additional data analysis that is not done in a typical way and it is very valuable and informative. Since the data come from the national Registry which encompass complete population of those characteristics, and data collection were specified by legislation, neither of cases was excluded.

\section{Procedure}

The data were collected via online Pompidou form, a standardized questionnaire:

- recommended by the Council of Europe. Treatment centres participating in the data;

- collection enter the data directly through the online platform of the register, which includes all;

- questions from the Pompidou form. Patients are identified uniquely using their national;

- identification number in order to prevent double registration and double counting of the same;

- person in the report. A lot of treatment facilities are able to participate in the collecting data for the registry, which availables a wide coverage of the population.

\section{Questionnaire}

Pompidou questionnaire (Katalinić \& Huskić 2017, HZJZ 2019) and International Statistical Classification of Diseases and Related Health Problems (ICD-10) codes from F11 to F19 (Kuzman 2012) were used for registration. Questions from the Pompidou questionnaire were based on socio-demographic information and information about treatment, risky behavior and legal problems, which were strictly confidential (Croatian Institute of Public Health 2019).

\section{Statistical analysis}

We used descriptive statistics to show apsolute numbers, chi-square test to determine whether the obtained frequencies deviate from the expected frequencies under a particular hypothesis and binary logistic regression to assign which characterictics can predict the abstinence status of the treated person. The dependent variable is the result of treatment which takes on two possible outcomes - a value of 0 (does not abstain) and 1 (abstains - stable). We chose gender and the way of referral as predictor variables. Gender is a dichotomous variable in which we can see how many times abstinence is more likely to occur in males than in females. The method of referral is a variable that we divided into the following modalities: "Personal, family, friends", "Health institution", "Police, Municipal State Attorney's Office, court" and "Social Welfare Center". The ratio of chances is analysed in relation to the reference category, and in our case it is the category "Police, Municipal State Attorney's Office, court". Both statistical tests were performed in the SPSS program.

\section{RESULTS}

In table 1 registrated persons are classified based on their gender and based on the time of their first treatment. According to that, men take cannabinoids more than women. There were less registrated people because of cannabinoids abuse in 2009 compared to 2008, but after that the number was increasing and achieved maximum in 2014. From 2014 to 2016 the numbe of registrated people was decreasing and after that the trend of increasing continued and year 2018 stands out by number of people treated for the first time in that year.

Table 2 shows registrated people based on their age and working status. The most registrated people had been aged 20-24 years until 2009, but after that the age limit went down and the most registrated people has been agred 15-19 years. According to that, based on working status, the most people were students, unemployed or they have an occasional job, what made it difficult to prescribe a fine because it was about people without permanent financial income. Registrated persons were referred to treatment personally, by family, friends, general practicioner, hospitals and other medical institutions, centre for social care and the court or police, but for some of them, data were unknown. 
Table 1. Number of patients treated for the first time in certain year and patients treated before that year

\begin{tabular}{|c|c|c|c|c|c|c|c|c|c|}
\hline \multirow{3}{*}{$\frac{\text { Year }}{2008}$} & \multirow{2}{*}{\multicolumn{2}{|c|}{$\begin{array}{l}\text { Treated for } \\
\text { the first time }\end{array}$}} & \multirow{2}{*}{\multicolumn{2}{|c|}{$\begin{array}{c}\text { Treated before } \\
\text { that year }\end{array}$}} & \multicolumn{5}{|c|}{ Total } \\
\hline & & & & & & & & $\operatorname{lan}$ & All \\
\hline & 592 & $60.16 \%$ & 392 & $39.84 \%$ & 895 & $90.96 \%$ & 89 & $9.04 \%$ & 984 \\
\hline 2009 & 420 & $60.26 \%$ & 277 & $39.74 \%$ & 620 & $88.95 \%$ & 77 & $11.05 \%$ & 697 \\
\hline 2010 & 606 & $67.48 \%$ & 292 & $32.52 \%$ & 792 & $88.20 \%$ & 106 & $11.80 \%$ & 898 \\
\hline 2011 & 619 & $62.65 \%$ & 369 & $37.35 \%$ & 864 & $87.44 \%$ & 124 & $12.56 \%$ & 988 \\
\hline 2012 & 675 & $64.16 \%$ & 410 & $35.84 \%$ & 927 & $88.11 \%$ & 125 & $11.89 \%$ & 1052 \\
\hline 2013 & 671 & $62.01 \%$ & 411 & $37.99 \%$ & 912 & $84.29 \%$ & 170 & $15.71 \%$ & 1082 \\
\hline 2014 & 700 & $61.03 \%$ & 447 & $38.97 \%$ & 985 & $85.88 \%$ & 162 & $14.12 \%$ & 1147 \\
\hline 2015 & 528 & $53.55 \%$ & 458 & $46.45 \%$ & 871 & $88.34 \%$ & 115 & $11.66 \%$ & 986 \\
\hline 2016 & 469 & $59.75 \%$ & 316 & $40.25 \%$ & 668 & $85.10 \%$ & 117 & $14.90 \%$ & 785 \\
\hline 2017 & 612 & $63.82 \%$ & 348 & $36.18 \%$ & 802 & $83.54 \%$ & 158 & $16.46 \%$ & 960 \\
\hline 2018 & 803 & $84.08 \%$ & 152 & $15.92 \%$ & 803 & $84.08 \%$ & 152 & $15.92 \%$ & 955 \\
\hline
\end{tabular}

Table 3 shows the way of referral in certain years. The most people were referred to treatment by police in every of observed year, center for social welfare is on the second place and family on the third. Since 2016 the percent of self-reported people to treatment has been increasing. Friends, general practicioner, hospitals and other medical institutions referred to treatment because of cannabinoids abuse very rarely.

Table 4 shows applications and results of treatments. The highest and the dominant number of treatments were in Department for prevention and outpatient treatment for addiction (18 388) whereas on the second place was hospital treatment, but with convincingly lower number of cases (2 159). The least number of patients were treated within the therapeutic community (278) and day hospital (52).

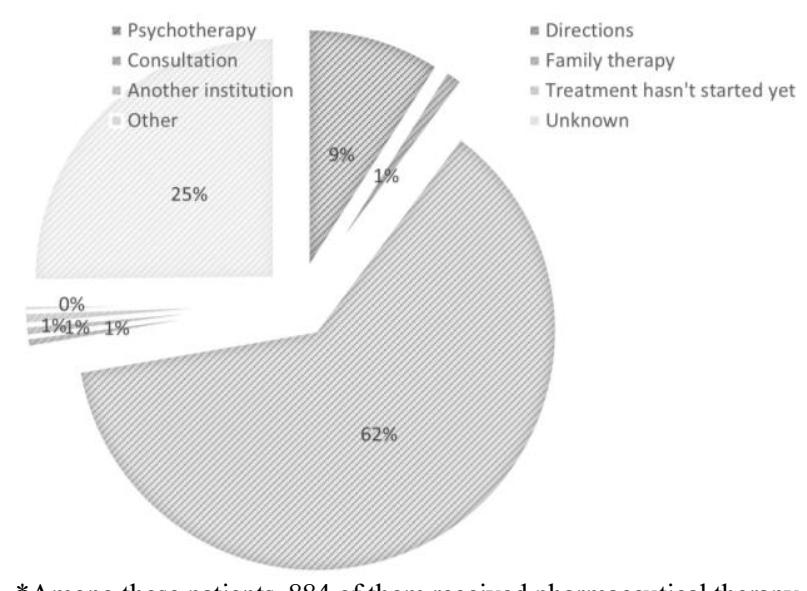

*Among these patients, 884 of them received pharmaceutical therapy

Figure 1. The type of treatment

Figure 1. shows which ways of treatment were used and that mostly it was about consultations $(62 \%)$. For 25 $\%$ of patients' data were unknown and on the third place there was psychotherapy with $9 \%$ of cases. Family therapy, giving directions and referral to another institution were used in small number of cases. Also, there wasn't any treatment for patients in very small number of cases.
Results of treatments showed that there were almost the same number of apstinents (5 724) and people who sometimes took cannabinoids (5 734) and these results were the most common. Chi-square test showed a statistically significant difference between apstinents and patients with unchanged status if these treatments were used: "family therapy", "support", "referred to another institution" and "the treatment hasn't started yet" (Table 5). Treatments "support" and family therapy were more common in patients with unchanged status after treatment. Also, patients with unchanged status were significantly more often referred to another health institution, whereas in apstinents the treatment hasn't started yet in more cases. The most common used the way of treatment was consultation, but there wasn't statistically significant difference between apstinents and patients with unchanged status after treatment. Chi-square test showed statistically significant difference between apstinents and patients with unchanged status after treatment according to all ways of referral written in the table 5. Apstinents were more often referred by family, centre for social welfare, court and police. Patients with unchanged stauts after treatment were more often referred by themselves, friends, Department for prevention and outpatient treatment for addiction, general practicioner and hospital.

To examine which characteristics affect the probability of abstinence, we used a binary logistic regression. Omnibus tests (Table 6) showed significance at a level of less than $5 \%$. Based on that, we can say that the model has increased its ability to explain compared to the model only with the constant. The Hosmer and Lemeshow test indicate that the model is well adapted to the data, according to the statistically insignificant chi-square indicator. Pseudo $\mathrm{R}^{2}$ in the table showed that the predictor variables are about $3 \%$ and explain the changes in the dependent variable, while the classification table showed the specificity, ie the percentage of accurate prediction of a negative result $(78.8 \%)$ and sensitivity, ie the percentage of abstainers correctly predicted (28.1\%). In the results table, the first column of the table showed the coefficients of binary logistic regression, 


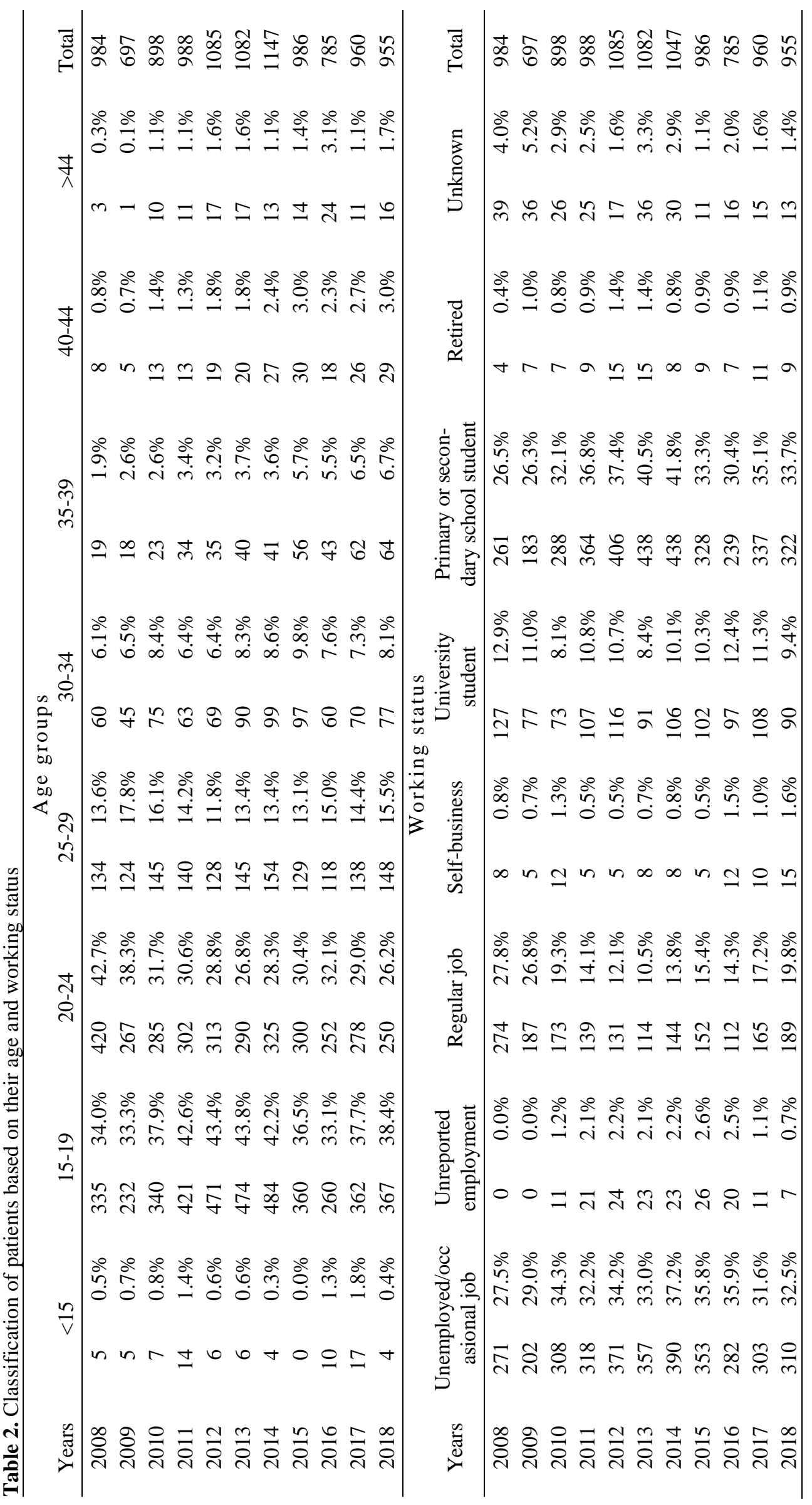




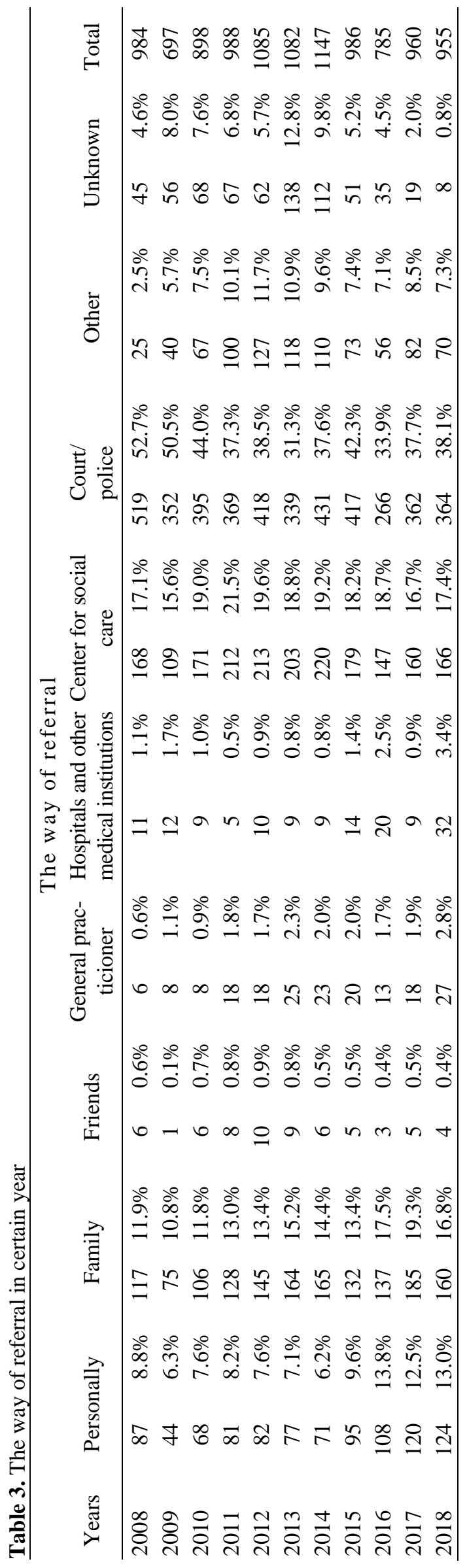


Table 4. Applications and results of treatments

\begin{tabular}{lc} 
Tretment & Total \\
\hline $\begin{array}{l}\text { Department for prevention and } \\
\text { outpatient treatment for addiction }\end{array}$ & 18338 \\
Hospital - ambulance & 2159 \\
Hospital - stationary & 2058 \\
Day hospital & 52 \\
Therapeutic community & 278 \\
Other & 2 \\
\hline Result of treatment & Total \\
\hline Apstinent & 5724 \\
Apstinent for the main drug, & 94 \\
but takes another & \\
Sometimes takes the main drug & 5734 \\
Unchanged & 2328 \\
Treatment hasn't started yet & 1345 \\
Unknown & 7662 \\
\hline
\end{tabular}

while the last column represents the odds ratio in logistic regression, ie the element to be interpreted. The predictor variables are gender and the source of referral. In the case of gender, the odds ratio in binary logistic regression shows how many times the abstinence is more likely to occur in one gender than in the other. In case of source of referral the odds ratio refers to the reference category "referred by the police, the municipal state attorney's office or the court". The results showed that there was no statistically significant difference between men and women when it comes to the probability of abstinence, and the same is among persons referred by the police, the municipal state attorney's office or the court. The police, the municipal state attorney's office, and the court were also the reference category for the variable "The way of referral". In the case of the categories "Personally, family, friends" and "Health care institution", the abstinence status of persons referred in this way was less likely than in the reference category, while those referred by the center for social care were about 1.3 times more likely to be abstainers compared with the reference category.

Table 5. Chi-square test for the way of treatment, the way of referral and results of treatment

\begin{tabular}{|c|c|c|c|c|}
\hline & Apstinent (stable) & Unchanged status & Total & Chi-square \\
\hline \multicolumn{5}{|l|}{ The way of treatment } \\
\hline Psychotherapy & 536 & 176 & 712 & 13.924 \\
\hline Directions & 96 & 42 & 138 & 6.164 \\
\hline Consultation & 3958 & 1456 & 5414 & 12.895 \\
\hline Family therapy & 25 & 19 & 44 & $16.047 *$ \\
\hline Support & 70 & 58 & 128 & $34.738 * *$ \\
\hline Referred to another institution & 19 & 45 & 64 & $77.450 * *$ \\
\hline The treatment hasn't started yet & 11 & 41 & 52 & $88.084 * *$ \\
\hline Other & 21 & 3 & 24 & 12.299 \\
\hline Total & 4736 & 1840 & 6576 & \\
\hline \multicolumn{5}{|l|}{ Referred by } \\
\hline Personally & 393 & 129 & 522 & $14.938 *$ \\
\hline Family & 625 & 678 & 1303 & $67.513 * *$ \\
\hline Friends & 29 & 13 & 42 & 4.136 \\
\hline $\begin{array}{l}\text { Department for prevention and outpatient } \\
\text { treatment for addiction }\end{array}$ & 14 & 13 & 27 & $15.810 *$ \\
\hline General practicioner & 92 & 56 & 148 & $17.251 *$ \\
\hline Hospitals and other health institutions & 88 & 54 & 142 & $17.256^{*}$ \\
\hline Centre for social care & 1393 & 382 & 1775 & $66.054 * *$ \\
\hline Court/Police & 2522 & 766 & 3288 & $69.314 * *$ \\
\hline Total & 5156 & 2091 & 7247 & \\
\hline
\end{tabular}

Table 6. Results of binary logistic regression

\begin{tabular}{lcccccc} 
& \multicolumn{1}{c}{ B } & S.E. & Wald & df & Sig. & Exp (B) \\
\hline Gender & -0.048 & 0.067 & 0.524 & 1 & 0.469 & 0.953 \\
The way of referral & & & 187.809 & 3 & 0.000 & \\
Personally, family, friends & -0.598 & 0.056 & 114.691 & 1 & 0.000 & 0.550 \\
Healthcare institution & -0.371 & 0.117 & 10.091 & 1 & 0.001 & 0.690 \\
Center for social care & 0.228 & 0.054 & 17.999 & 1 & 0.000 & 1.256 \\
Constante & -0.047 & 0.069 & 0.468 & 1 & 0.494 & 0.954 \\
\hline
\end{tabular}

Cox i Snell R Square 0.022; Nagelkerke R Square 0.3; Hosmer and Lemeshow Test: Chi-square: 5.429; Df: 3; Sig. 0.143; Classification table: $56.4 \%$; Sensitivity: $28.1 \%$; Specificity: $78.8 \%$ 


\section{DISCUSSION}

The advantage of this study is that the analysis is based on data from the Registry which includes data from the total population, not from a sample. Furthermore, the advantage is that over a long period, 10 years, the same data is collected in the same way and can be compared. The limitation is that any additional data cannot be collected from persons because data collection was specified for Registry by legislation.

Results showed changing trend of registrated people in a ten-year period. Men take cannabinoids more than women and also more and more young people are registrated because of cannabinoids abuse which get on well with world trends (Cuttler et al. 2016). The most registrated people were referred by repressive way, which makes question of its efficiency and prevention of long term addiction, because system like that more likely stigmatizes and punishes young people, opposite to giving support and help. Those referred by repressive mechanism are more likely to have the abstinence status, but it could be explained by the desire to avoid fines, not real addiction. It is easier for them to stop taking cannabinoids if they weren't addicted. Comparing the different repressive ways, those referred by center for social welfare have higher chance of abstinence status, which can be explained by a greater assessment of the need for treatment. The chi square test showed that persons referred by family were more often abstainers, but in binary logistic regression referral by family is classified in the category of unrepressive referral, which is the category with the result of less abstinence. Abstination of people reffered by family can be explained by family support, but also with avoiding the payment of punish, because mostly of them were studens, so parents needed to pay for them. The most commonly used the way of treatment is consultation, , but results showed that there wasn't significant difference between apstinents and patients with unchanged status, which makes conclusion that something needs to be wrong with that treatment. According to data of European Monitoring Centre for Drugs and Drug Addiction (EMCDDA), 16\% of Croatian citizens aged 15-34 years were taking cannabis in 2017. European countries with a higher percent of cannabis consumers were Netherlands (17.5\%), Czech Republik (19.3\%), Spain (18.3\%), Italy (20.9\%) and France (21.8\%) (European Monitoring Centre for Drugs and Drug Addiction 2017). Drug use in the Netherlands is not a crime, but in some situations, it is prohibited at the local level in order to protect the health of young people or for reasons of public order, such as at schools and on public transport. Imprisonment is the punishment for the possession of small quantities of drugs for personal use, but, in practice, it is not a case. If the police finds somebody in in possession of a small amount of drugs for personal use, in generally, he will not be pursued, but the police will seize the drugs. Cannabis sales and consumption outlets, known as 'coffee shops', may be tolerated by local authorities only under strict conditions which are following The Opium Act (Colson \& Bergeron 2017). In Czech Republik drug use is not, but the cultivation or possession of small quantities for personal use is a noncriminal offence punishable by a fine (The Library of Congress 2016), whereas in Spain the both situations are non-criminal offences, punishable by fines. For minor Spaniards, the fine can be suspended if the offender voluntarily attends treatment, rehabilitation or consultation activities (The European Monitoring Centre for Drugs and Drug Addiction 2019 a). There are differences between Spanish regions. In Catalonia system is liberal, whereas in Madrid is more strict with higher fines (Euronews 2013), but there is dissatisfaction in both regions in opinions of doctors and lawyers (Rossi et al 2018). Drug use in Italy is not specified as an offence, but the punishment for the possession for personal use are administrative sanctions, such as the suspension of a driving licence, that could be completed with a socio-rehabilitation and therapeutic programme (The European Monitoring Centre for Drugs and Drug Addiction 2019 a, Mosher \& Akins 2007). The use and possession of illicit drugs are criminal offences in France. In simple cases, drug users may receive a caution, but for all offenders aged over 13 years this should usually be accompanied by a requirement to attend a compulsory drug awareness course, introduced in March 2007, for which an offender may have to pay. The implementation of educational and health interventions is a priority for simple drug crimes (Drug Policy Consortium 2010). Countries with the lowest prevalence of cannabis use are Turkey (1.8\%), Hungary (3.5\%), Cyprus (4.3\%), Greece (4.5\%), Romania (5.8\%), Litva (6.0\%) and Portugal (8\%). Eventhough Turkey is a country with the lowest percent of cannabis consuments, in last few years there has been increasing in volume of drugs used in that country and drugs that are part of transport through that country (Brookings 2014). The punishment for buying, receiving, cultivating or possessing drugs for personal use is imprisonment of 1-2 years. There is also the option of treatment and/or probation of up to 3 years (The European Monitoring Centre for Drugs and Drug Addiction 2019 a). Since year 2013, Drug consummation has been a criminal offence in Hungary punishable by up to 2 years in prison. Possession is punishable by imprisonment up to 2 years if it involves small quantities. There is option of healthcare treatment and suspension of the prosecution only if the offender had small quantities of drugs, but this option is not available within 2 years of a previous suspension (The European Monitoring Centre for Drugs and Drug Addiction 2019 a, International drug policy guide 2013). Possession for personal use in Cyprus is specified as a serious criminal offence, punishable by imprisonment. In recent years, there has been trying to introduce alternative sanctions. In the pre-trial phase, there is an alternative to referre young offenders 
arrested for the first time to the healthcare treatment. New law, introduced in 2016, allow self-applying for the treatment for those who are accused of drug-related offences other than supply and serious felony. Although drug possession is considered a serious crime, cultivation and use of medical cannabis for personal use has been legalized since 2019 (Healtheuropa 2019). The Greek law introduced in 2013, specifies imprisonment up to 5 months for offenders who use, obtain, process or cultivate cannabis for personal use. If the offender does not any other criminal offence in the period of 5 years, the drug offence is not recorded on the offender's criminal record. Offenders may be referred to a special treatment unit operating in a prison setting or a community drug treatment programme operated by a lawfully recognised agency if the investigating judge decides like that. Offenders who have already been attending the treatment, may avoind the punishment (The European Monitoring Centre for Drugs and Drug Addiction 2019a, Lambropoulou 2003). According to Criminal Code from 2014 Drug consumption is illegal in Romania, but punishment is not specified. In the case of possession for personal use, the court can impose a fine or imprisonment from 3 months to 2 years, or from 6 months to 3 years, depending on the type of drug. In the case of a drug user who agrees to be referred to the treatment, the punishment may be suspended (The European Monitoring Centre for Drugs and Drug Addiction 2019 a, Dégi 2004). Consumption of drugs is an administrative offence in Latvia, punishable by a fine of 30 to 150 euros for a first offence with possible referring to the treatment. Since January 2017, procurement and possession of a small amount of an illicit drug for personal use has been a criminal offence punishable by community service or restriction of liberty, but nonprison incarceration of 10 to 45 days (The European Monitoring Centre for Drugs and Drug Addiction 2019, Ivančiks et al. 2015). Among these countries with a low percentage of cannabis use, the most interesting is Portugal, which is the only EU country with decriminalized (not legalized) use of all drugs for personal use. The Drug Decriminalization Act of 2001 proved to be very successful in Portugal, since its introduction has reduced the prevalence of all drugs, which is now among the lowest in Europe (Greenwald \& Glenn 2009). The regulation specifies maximum amounts of drugs in grams for 10 days of consumption. The local drug committee evaluate a person who is uses or possesses a small amount of drug for personal use, unless he/she is involved in the drug trade. The drug committee consists of three members, two of them are physicians, psychologists, sociologists, or social workers, and the third member is a legal professional. Penalties may apply, but the main goals are to investigate the need for treatment and to promote healthy recovery. Portugal is a great example how successful interventions don't have to be very strict and repressive if their use is apropiate (The European Monitoring Centre for Drugs and Drug
Addiction 2019 a, The European Monitoring Centre for Drugs and Drug Addiction 2019 b). Future research should be more focused on effective preventive interventions, as well as the outcomes and implications of therapeutic interventions with the aim of finding the best models for the prevention and treatment of cannabis addiction. Recommendation for further studies is to explore regional differences and specificity of these population groups and to explore treatment outcome in relation to other parameters that are not analyzed in this research paper.

\section{CONCLUSION}

Croatia was above European average in cannabis use in age groups from 15 to 34 years in 2017 according to data of European Monitoring Centre for Drugs and Drug Addiction. Results of research in a ten-year period from 2008 to 2018 showed that there hadn't been significant changes in decreasing and increasing in number of registrated people because of cannabinoids abuse, but it is possible to see difference in number of registrated people in certain year, so the year 2018 is specific based on the high number of patients treated for the first time in that year.. More and more young people are registrated because of cannabinoids abuse. Interventions used in Croatia, except fines and imprisonment up to 90 days, are interventions of obligatory treatment in healthcare institution without fine or imprisonment up to 90 days if the offense has been done for the first time and with fine or imprisonment up to 90 days if it is about addict or occasional drug user (Zakon o izmjenama i dopunama Zakona o suzbijanju zlouporabe droga 2019). The most commonly used intervention of obligatory healthcare treatment is consultation, but there is no statistically significant difference between apstinents and people with unchanged status. There are the most people directed by police in every of observed years, in the second place there is Centre for social care and in the third family. The highest probability of abstinence is in the case of a referral from a center for social care. European countries with high percent of cannabis users mostly have liberal laws, whereas countries with low percent have strict laws and very high penalties for breaking the law. The only exception is Portugal, which is a great example how successful interventions don't have to be very strict and repressive if their use is apropiate (The European Monitoring Centre for Drugs and Drug Addiction 2017, The European Monitoring Centre for Drugs and Drug Addiction 2019 b). Inadequate implementation of the protective measure of compulsory treatment puts a burden on the health system, the people who don't need a treatment are referring to it, which costs and take away the doctor's time for those who really need help. That's why it is very important to have a committee that will evaluate the person caught in the offense and refer to the healthcare institutions those who really need it to be treated. 


\section{Acknowledgements: None.}

\section{Conflict of interest: None to declare.}

\section{Contribution of individual authors:}

Dora Milaković: Conception and design of the study, analysis and interpretation of data, drafting of the manuscript, critical revision of the manuscript for important intellectual content, final approval of the version to be submitted, agreement to be accountable for all aspects of the work.

Danijela Štimac Grbić: Conception and design of the study, acquisition of the data, analysis and interpretation of data, drafting of the manuscript, critical revision of the manuscript for important intellectual content, final approval of the version to be submitted, agreement to be accountable for all aspects of the work.

Maja Valentić: Conception and design of the study, acquisition of the data, analysis and interpretation of data, critical revision of the manuscript for important intellectual content, final approval of the version to be submitted, agreement to be accountable for all aspects of the work.

Gorka Vuletić: Analysis and interpretation of data, critical revision of the manuscript for important intellectual content, final approval of the version to be submitted, agreement to be accountable for all aspects of the work.

Ivana Pavić Šimetin: Acquisition of the data, final approval of the version to be submitted, agreement to be accountable for all aspects of the work.

\section{References}

1. Arias F, Szerman N, Vega P, Mesias B, Basurte I, Morant $C$ et al.: Abuse or dependence on cannabis and other psychiatric disorders. Madrid study on dual pathology prevalence. Actas Esp Psiquiatr 2013; 41:122-129

2. Brookings [Internet]. Brookings; 2016. Amped in Ankara: Drug trade and drug policy in Turkey from the $1950 \mathrm{~s}$ through today; [Updated 2016, cited $2020 \mathrm{Apr} 11]$; [20 pages]. Available from: https://www.brookings.edu/wpcontent/uploads/2017/04/fp_201704_turkey_drug_policy.pdf

3. Bifulco $M \&$ Pisanti $S:$ Medical use of cannabis in Europe. EMBO Rep 2015; 16:130-132

4. Colson $R \&$ Bergeron H: Drug Policy in The Netherlands. In Colson R, Bergeron H (eds.): European drug policies: the ways of reform, 128-148. Routlege, 2017

5. Croatian Institute of Public Health [Internet]. Croatian Institute of Public Health, 2019. Upute za ispunjavanje individualnih zdravstveno-statističkih izvješća, [Updated 2019, cited 2020 Dec 4]; [39 pages]. Available from: https://www.hzjz.hr/wp-content/uploads/2013/11/uputezuta-knjiga

6. Cuttler C, Mischley LK, Sexton M: Sex Differences in Cannabis Use and Effects: A Cross-Sectional Survey of Cannabis Users. Cannabis Cannabinoid Res 2016; 1: 166-175

7. Dégi CL: Romania's Drug Policy from 2005 to 2012: Experiences with Implementation. Substance Use \& Miuse 2014; 49: 677-683
8. ElSohly MA, Radwan MM, Gul W, Chandra S, Galal A: Phytochemistry of Cannabis sativa L. Prog Chem Org Nat Prod 2017; 103:1-36

9. Euronews [Internet]. Euronews, 2013. Spain: where drug consumption is not a crime, [Updated 2013 Nov, cited 2020 Apr 11]; [1 page]. Available from:

https://www.euronews.com/2013/11/06/spain-where-drugconsumption-is-not-a-crime

10. Greenwald \& Glenn: Drug Decriminalization in Portugal: Lessons for Creating Fair and Successful Drug Policies. Cato Institute, Washington, 2001.

11. Healtheuropa [Internet]. Healtheuropa, 2019. Medical cannabis law approved in Cyprus, [Updated $2019 \mathrm{Feb}$, cited 2020 Apr 11]; [1 page]. Available from: https://www.healtheuropa.eu/medical-cannabis-lawcyprus/90507/

12. International Drug Policy Consortium [Internet]. International Drug Policy Consortium; 2010. IDPC Drug Policy Guide (Politiques Des Drogues - Un Guide De L'IDPC) (French); [Updated 2011 Aug, cited 2020 Apr 11]; [131 pages]. Available from SSRN: https://ssrn.com/abstract $=$ 1910607 or http://dx.doi.org/10.2139/ssrn.1910607

13. International drug policy consortium [Internet]. International drug policy consortium, 2013. Drug law in Hungary: HLCU's guide for foreigners, [Updated 2013 Aug, cited 2020 Dec 4]. Available from https://idpc.net/alerts/ 2013/08/drug-law-in-hungary-hclu-s-guide-for-foreigners

14. Ivančiks J, Tumalavičius $V$, Treivans-Treinovskis JS: Security of society: Narcotics and drug adiction in Latvia and Lithuania. Journal of Security and Sustainability Issues 2015; 4: 353-368

15. Katalinić $D \&$ \&uskić A. Report on persons treated for drug abuse in Croatia in 2017. Croatian Institute of Public Health, Zagreb, 2017

16. Kuzman M: Međunarodna klasifikacija bolesti i srodnih zdravstvenih problema- deseta revizija: Mentalni poremećaji i poremećaji ponašanja (F00-F99). Medicinska naklada, Zagreb, 2012.

17. Lambropoulou E: Drug Policy in Greece: A Balance between Enforcement and Persuasion. European Journal of Crime, Criminal Law and Criminal Justice 2003; 11:18-39

18. Mehanović E, Virk HK, Akanidomo I, Pwajok J, Prichard $G$, van der Kreeft P: Correlates of cannabis and other illicit drugs use among secondary school adolescents in Nigeria. Drug Alcohol Depend 2019;_206:107-457.

19. Ministarstvo pravosuda i uprave [Internet]. Ministarstvo pravoduđa i uprave, 2012. Prijedlog zakona o izmjenama $i$ dopunama kaznenog zakona, [Updated 2012, cited 2020 Mar 30]. [64 pages]. Available from: https://pravosudje.gov.hr/posjedovanje-droge-zaosobnu-uporabu-prekrsajno-a-ne-kazneno-djelo/6388

20. Mosher CJ, Akins S. Drugs and Drug Policy. In The Control of Consciousness Alteration (eds): Sage Publications Ltd, 378-379. London, 2007

21. Narodne novine: Zakon o suzbijanju zlouporabe opojnih droga. Zagreb: Narodne novine d. d., 2001; 107:1

22. Narodne novine: Zakon o izmjenama i dopunama Zakona o suzbijanju zlouporabe droga. Zagreb: Narodne novine d. d., 2019;39:8

23. Osuch E, Vingilis E, Ross E, Forster C, Summerhurst $C$ : Cannabis use, addiction risk and functional impairment in youth seeking treatment for primary mood or anxiety concerns. Adolesc Med Health 2013; 25:309-314 
24. Rossi P, Blay E, Costela V, Torrens M: Illicit drug policy in Spain: the opinion of health and legal professionals. Adicciones 2018; 30:33-40

25. Simpson AK \& Magid V: Cannabis Use Disorder in Adolescence. Child Adolesc Psychiatr Clin N Am 2016; 25:431-443

26. Teesson M, Slade T, Wendy S, Mills K, Memedovic S, Mewton L et al.: Prevalence, correlates and comorbidity of DSM-IV Cannabis Use and Cannabis Use Disorders in Australia. Australian \& New Zeland Journal of Psychiatry 2015; 46:1182-1192

27. The European Monitoring Centre for Drugs and Drug Addiction [Internet]. The European Monitoring Centre for Drugs and Drug Addiction, 2017. Country Drug Report 2017; [Updated 2017, cited 2020 Apr 13]. Available from: http://www.emcdda.europa.eu/countries/drug-reports/2017

28. The European Monitoring Centre for Drugs and Drug Addiction [Internet]. The European Monitoring Centre for Drugs and Drug Addiction, 2019. Country Drug Report
2019; [Updated 2019, cited 2020 Mar 30]. Available from: http://www.emcdda.europa.eu/countries/drug-reports/2019

29. The European Monitoring Centre for Drugs and Drug Addiction [Internet]. The European Monitoring Centre for Drugs and Drug Addiction, 2019. European Drug Report 2019; [Updated 2019, cited 2020 Apr 11]; [98 pages]. Available from: https://www.emcdda.europa.eu/system/files/ publications/11364/20191724_TDAT19001ENN_PDF.pdf

30. The Library of Congress [Internet]. The Library of Congress, 2020. Decriminalization of Narcotics: Czech Republic, [Updated 2020 Dec, cited 2021 Jan 11]. Available from: https://www.loc.gov/law/help/decriminalization-ofnarcotics/czechrepublic.php

31. Turner SD, Spithoff S, Kahan M: Approach to cannabis use disorder in primary care - Focus on youth and other highrisk users. Canadian Family Psysician 2014; 60:801-808

32. Zakon. hr [Internet]. Zakon.hr, 2019. Prekršajni zakon, [Updated 2019 Jan, cited 2020 Mar 30]. Available from: https://www.zakon.hr/z/52/Prekr\%C5\%Alajni-zakon

Correspondence:

Dora Milaković, MD

University of Zagreb, Faculty of Medicine, School of Public Health

Rockfellerova 7, 10000 Zagreb, Croatia

E-mail: milakovicdora@gmail.com 